\title{
A comparison of the insulinotropic and enterogastric response to ingestion of an equivalent quantity of maltodextran and whey protein
}

\author{
O. Power ${ }^{1}$, C. Conway ${ }^{2}$, W. McCormack ${ }^{2}$, F. Oharte ${ }^{3}$, D. Fitzgerald ${ }^{1}$ and P. Jakeman ${ }^{2}$ \\ ${ }^{1}$ Food for Health Ireland, Department of Life Sciences, University of Limerick, ${ }^{2}$ Food for Health Ireland, Faculty of \\ Education and Health Sciences, University of Limerick, Plassey Technological Park, Limerick, Republic of Ireland \\ and ${ }^{3}$ School of Biomedical Sciences, University of Ulster, Coleraine, N. Ireland
}

In the absence of carbohydrate, the insulinotropic effect of whey protein ingestion induces a rise in plasma insulin and lowering of blood glucose during the first $30 \mathrm{~min}$ after ingestion (Power et al. 2009) ${ }^{(1)}$. It was hypothesized that the insulinotropic action of whey protein may, in part, be mediated via the secretion of the enterogastric hormones, represented by glucagon-like peptide-1 (GLP-1).

The present paper reports on the post-prandial response of plasma glucose, insulin and GLP-1 to feeding maltodextran and an equivalent quantity of whey protein. With ethical approval and informed consent four young, healthy subjects $(n=4$, age $25(2.8)$ y, BMI $21.8(1.1) \mathrm{kg} / \mathrm{m}^{2}$ ) undertook a randomized trial of two treatments, either a protein (WHEY $0.33 \mathrm{~g} / \mathrm{kg}, 10 \% \mathrm{w} / \mathrm{v}$ water) or maltodextran (MALT; $0.33 \mathrm{~g} / \mathrm{kg}, 10 \% \mathrm{w} / \mathrm{v}$ water), each treatment separated by 5 days. Subjects fasted overnight (10 h) prior to participation. Serial blood samples were withdrawn prior to and post ingestion for a period of $2 \mathrm{~h}$ and batch analysed for glucose, insulin and total GLP-1. Data are presented as mean (SEM; $n=4)$. Area under the curve for plasma insulin or total GLP-1 (AUC $0-120$ ) was calculated by trapezoidal integration. Difference in the mean response was analysed by paired Student's t-test.
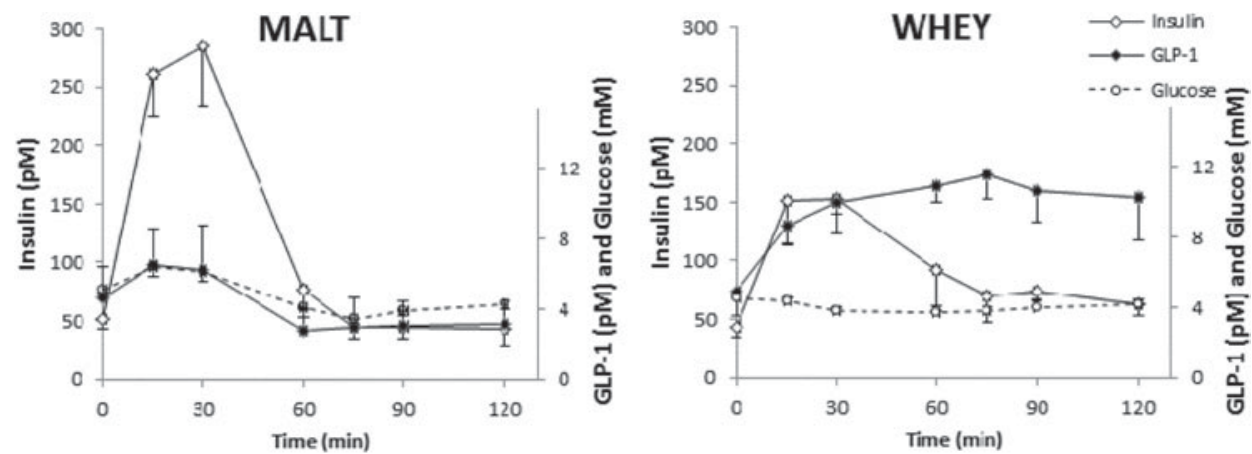

Figure 1. Mean plasma insulin, glucose and total GLP-1 for maltodextran (MALT) and whey protein concentrate (WHEY) during the post-prandial period. Values are mean $(\mathrm{SEM} ; n=4)$.

Following ingestion of the MALT, plasma insulin increased rapidly in the first $30 \mathrm{~min}$ and reached a maximal concentration $\left(\mathrm{C}_{\mathrm{max}}\right)$ of 299(48) pM which directly correlated with the change in plasma glucose (Fig. 1). Ingestion of WHEY resulted in a $\mathrm{C}_{\max }$ for plasma insulin of 182(23) pM within $30 \mathrm{~min}$ and was independent of a change in plasma glucose (Fig. 1). The differing insulin responses for MALT and WHEY were reflected in the AUC, 8506(2059) vs. 6512(1368) pM.2 $\mathrm{h}(P=0.29)$. In contrast, ingestion of MALT gave a transient increase in total GLP-1 in the first $30 \mathrm{~min}$ and a $\mathrm{C}_{\max }$ of 7.4(3) pM but ingestion of WHEY gave a prolonged increase with a $\mathrm{C}_{\max }$ of 11.4(2) $\mathrm{pM}$ at $75 \mathrm{~min}$. Total GLP-1 AUC was $-64(40)$ vs. 536(102) pM.2 h $(P=0.013)$ for MALT and WHEY, respectively.

The enterogastric response, GLP-1, was greater following ingestion of an equivalent protein (WHEY) versus carbohydrate (MALT) load. This contrasts with previous reports that GLP-1 secretion is glucose dependent ${ }^{(2)}$. There was a shift in the time course of maximal plasma insulin and GLP-1 response and this data does not support the hypothesis that GLP-1 directly mediates the insulinotropic action of protein. The magnitude of the protein mediated insulin response can be augmented by hydrolysis of the protein ${ }^{(3)}$; therefore future studies are warranted to examine the effect of protein hydrolysis and those of peptide components upon GLP-1 secretion.

All protein ingredients were kindly supplied by Carbery Ingredients. Work described herin was supported by Enterprise Ireland under grant number CC20080001.

1. Power O, Jakeman P \& Hallihan A (2009) 'Human insulinotropic response to oral ingestion of native and hydrolysed whey protein.' Amino Acids 37(2), 333-9.

2. Holst JJ \& Gromada J (2004) 'Role of incretin hormones in the regulation of insulin secretion in diabetic and nondiabetic humans'. Am J Physiol Endocrinal Metab 287, E199-E206

3. Claessens M, Saris WHM \& van Baak MA (2008) 'Glucagon and insulin responses after ingestion of different amounts of intact and hydrolysed proteins.' Br J Nutr 100(1), 61-9. 